\title{
MEMPELAJARI KONDISI OPTIMUM PEMBUATAN BIOETANOL MELALUI HIDROLISIS ENZIMATIS MENGGUNAKAN Sacharomycess cereviceae DARI PATI SAGU DAN UMBI TALAS
}

\author{
Marniati Salim, Elida Mardiah, Yosi Opthymal, Febby Febrizal \\ Laboratorium Bioteknologi, Jurusan Kimia, FMIPA, Universitas Andalas \\ Email: bundosalim@gmail.com
}

\begin{abstract}
Sago (Metroxylon sp) and umbi talas (Colocasia gigantea Hook $F$ ) are natural resources that are found in plantyfull Indonesian. However, these potencies are not yet processed to give an optimum value added product. Sago and taro are rich of starch, that could be fermented to form bioethanol for reneweable energy. The ethanol were produced by fermenting the hydrolized starch of sago and taro with yeast. The starch of sago and taro were hydrolized enzymaticly by $\alpha$-amylase and glucoamylase. Sago and taro (15 g each) were grinded and hydrolized by $\alpha$-amylase and then by glucoamylase at the variation of volume of $4,5,6,7$, and $8 \mathrm{~mL}$ for $1,2,3,4$, and 5 hours. The glucose produced was measured by Somogy-Nelson methods. The product of sago hydrolysis were optimum with $6 \mathrm{~mL}$ of $\alpha$-amylase and $6 \mathrm{~mL}$ glucoamylase for 2 hours to give $59.11 \mathrm{~g} / \mathrm{L}$ of reducing sugar. The product of taro with $6 \mathrm{~mL} \alpha$-amylase and $7 \mathrm{~mL}$ glucoamylase for 4 hours which gave $64.22 \mathrm{~g} / \mathrm{L}$ of reducing sugar. The product of ethanol were analyzed by Gas Cromatography (GC). The maximum bioethanol production obtained optimum after 4 days fermentation of hydrolized sago starch and after 5 days fermentation of hydrolized taro starch which were $3.742 \%$ and $4.0123 \%$.
\end{abstract}

Key words: Bioethanol, sago starch, taro, enzymatic hydrolysed, $\alpha$-amylase and glucoamylase

\section{DAFTAR PUSTAKA}

1. Transportasi Massal Perlu Mendapat Prioritas (Konsumsi BBM Indonesia 2012), http://www.kompas.com, 12/03/ 2012.

2. R. D. Endah, K. A. Enny, dan N. Adrian, Bioetanol fuel grade dari talas (colocasia esculenta), Ekuilibrium., 8(1): 1-6, (2009).

3. N. Indyah, Teknologi proses produksi bioetanol. BPPT prospek pengembangan bio-fuel sebagai substitusi bahan bakar minyak (BBM), http://www.oocities.org/ markal_bppt/publish/biofbbm/biindy.pdf, 14/06/2012.

4. P. F. Akmar and J. F. Kennedy, The potential of oil and sago palm trunk wastes as carbohydrate resource, Wood Sci and Technol., 35: 467-473, (2001).
5. Y. Shunji, and S. Masaaki, a Simple method to determine bioethanol content in gasoline using two-step extraction and liquid scintillation counting, Bioresource Technology., 100: 6125-6128, (2009).

6. S. Ani, Pemafaatan talas (colocasiaesculenta) sebagai bahan baku pembuatan bioetanol, Universitas Diponegoro, Semarang, 1-12, (2011).

7. S. Komarayati, I. Winarni, dan Djarwanto, Pembuatan bioetanol dari empulur sagu (metroxylon spp.) dengan menggunakan enzim, Jurnal penelitian hasil hutan., 29(1): 20-32, (2011).

8. N. Siniša, Dodic,'D. P. Stevan, M. D. Jelena, A. R. Jovana, and Z. Z. Zoltan, potential contribution of bioethanol fuel to the transport sector of vojvodina, Renewable and Sustainable Energy Reviews., 13: 2197-2200, (2009). 
